\title{
Management of Industry and Technology
}

by

\author{
Kazutaka MUKOYAMA*
}

大学教員として着任してから約 2 年半. この度, 私が 学生時代から大変お世話になっている信頼性工学部門委 員会のご推薦により，会員便り執筆の機会をいただきま した。心よりお礼を申し上げます。今回は，私の所属す る大阪大学大学院工学研究科ビジネスエンジニアリング 専攻と私の研究活動についてご紹介します.

私の所属先であるビジネスエンジニアリング専攻. 周 囲からは,「カタカナが並んでいて格好良いイメージがあ るけれど, 何をしているのかさっぱりわからん!」と言 われることがあります。確かに専攻名だけではわかりに くいと思います．本便りをご覧くださっている皆様の中 にも，同じ意見をお持ちの方がいらっしゃることでしょ う.では, ビジネスエンジニアリング専攻とは何をする 専攻なのか? それは, 工学・経営学の両分野の教育プロ グラムを基に, 次世代の産業を担える人材（研究開発リー ダー, アントレプレナー, ファシリテーターなど）を育 成する専攻です，わかり易い言葉で言い換えると，「経営 がわかる技術者」,「技術がわかる経営者」の素養を育む 専攻です．技術と経営の両分野に長けた人材育成の必要 性が問われる中, 本学の工学研究科と経済学研究科が連 携し, 平成 16 年 4 月に工学研究科内に産声を上げました. 設立当初より, 本専攻は自然科学系と社会科学系を専門 とした教員で構成されており, 工学を軸に専門知識を深 めつつ, 経営学も含めた幅広い視野を育む教育プログラ ムを展開しています。さらに, 工学や経営学といった知 識教育だけでなく, 創造性, 問題設定・解決力, リーダー シップ力, 変化に対応する力を育成することを目的とし た「OJE (On the Job Education) 法」という本専攻独自 の実践型教育法を開発し, 実践しています。このOJE法 の教育プログラムの一つに「ビジネスエンジニアリング 研究」があります.これは, 少人数グループ制の実践型 演習で, 企業や地方自治体等と専攻教員が連携して設定 した課題に対して, 学生グループが議論をし, 企画・立 案から課題解決までのプロセス（考え方）を学びます. そのため, 研究評価対象は結果にあるのではなく, それ に至るプロセスにあります。本教育プログラムは, 日本 工学教育協会業績賞を 2 度受賞しており, 外部から高い

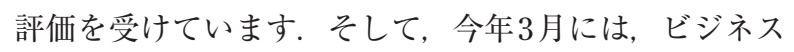
エンジニアリング研究で培われたアクティブラーニング を行うためのノウハウが満載の書籍「うまくやれる工学
のアクティブラーニング OJE」を本専攻と神戸大学 米谷 淳教授との編著で大阪大学出版会より出版しました．大 学, 企業を問わず，人材教育に携わる方やお困りの方は 必見です。なお, OJE法の詳細は専攻ホームページ (http:// www.mit.eng.osaka-u.ac.jp/）にも記載されておりますので, 是非一度, ご覧ください.

さて, ここまではビジネスエンジニアリング専攻の OJE法の教育プログラムについてご紹介しましたが, 本 専攻では, もちろん工学研究の活動にも力を注いでいま す．工学修士としての専門性は必須です。私の所属する テクノロジーデザイン講座（倉敷花木研究室）では,「信 頼性工学」,「複合材料工学」を軸に, テキスタイル複合 材料のマルチスケール解析技術, 複合材料製水素貯蔵夕 ンクの開発設計技術, 災害シミュレーション技術, 金属 材料.複合材料の疲労寿命推定法の開発など,「産学連携」, 「学学連携」,「異分野連携」をキーワードに研究活動を展 開しており, 研究室単体だけではなく, 産業界と直結し た基礎研究や技術開発にも積極的に取り組んでいます。 現在, 私の専門分野は「信頼性工学」,「複合材料工学」 ですが,「異分野連携」として,「昆虫工学」や「バイオ ミメティクス」に着目した研究も開始しました. 研究対 象は世界最大のへラクレスオオカブトムシ（学名： Dynastes hercules hercules). ヘラクレスオオカブトムシ の上翅構造は, 繊維強化複合材料の構造とそっくりで, キチン質の繊維が配向しています (図1). 外敵から身を 守るため, 大空を舞うために軽くて強い上翅. この上翅 構造を解明することで, 繊維強化複合材料の最適な材料 設計指針が得られ, 輸送機器分野やエネルギー分野に貢 献できるのではないかと期待しています.

今回は, ビジネスエンジニアリング専攻と私の研究活 動についてご紹介しました. 今後も, 実社会とのつなが りを意識した人材教育や工学研究の活動を行い, 学術界, 産業界に貢献できるよう努めていきます。

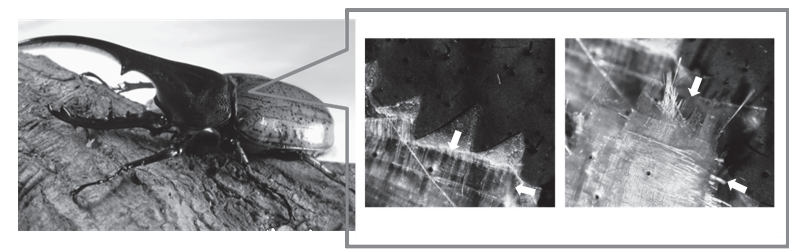

図 1 ヘラクレスオオカブトムシの上翅に扔けるキチン質層

$\dagger$ 原稿受理 平成 28 年 7 月 11 日 Received July 11, 2016 C2016 The Society of Materials Science, Japan

* 正 会 員 大阪大学大学院工学研究科＝565-0871 吹田市山田丘, Grad. Sch. of Eng., Osaka Univ., Yamadaoka, Suita, 565-0871 